\title{
Prevalence and Pathology Associated with Coccidian Parasite Eimeria tenella in Organised and Unorganised Poultry of Kashmir Valley, India
}

\author{
Sheikh Tanveer Salam ${ }^{1 *}$ and Showkat Ahmad Wani \\ ${ }^{1}$ Department of Zoology, GDC Ganderbal, J\&K (UT), India \\ ${ }^{2}$ Department of Zoology, SP College, Srinagar, J\&K (UT), India \\ *Corresponding Author: Sheikh T Salam, Department of Zoology, GDC Ganderbal, \\ J\&K (UT), India.
}

Received: February 26, 2021

Published: March 22, 2021

(C) All rights are reserved by Sheikh

Tanveer Salam and Showkat Ahmad

Wani.

\begin{abstract}
This study was carried out from January 2018 to December 2019 to know the prevalence and the pathology associated with the coccidian parasite Eimeria tenella in both organized poultry farms and unorganized backyard chickens of Kashmir valley. For this study a sample size of 400 intestinal caecae were collected from birds belonging to both organized farms and unorganized village backyard poultry of Kashmir valley. The overall prevalence of the parasite during a two year study was found to be $29.75 \%$. Higher prevalence (35.5\%) was recorded in backyard poultry as compared to the poultry birds in various organized farms (24\%). Mixed infection of E. tenella with other Eimerian species was also found to be comparatively higher in unorganized chicken than the organized poultry. The study revealed that the prevalence of Eimerian infection to be highest (76.47\%) during September months of both the years of study. Diagnosis of the coccidian species was done based on the identification of oocysts by morphometry. Infected caecae were preserved and subjected to histological studies which revealed disruption of epithelial lining and congestion of blood vessels. Submucosa of caecum reveals severe haemorrhage, muscular oedema and necrosis. Clusters of oocysts and microgametes were found to be lying free in the lamina propria of caecum. Sections revealed many intracellular schizonts containing merozoites with severe submucosal hemorrhage in caecum. Infected sites revealed massive infiltration of various heterophils and mononuclear cells. Overall histological changes cause reductions in the absorptive surfaces, with resultant decreased nutrient absorption, dehydration, blood loss and increased susceptibility to secondary infections.
\end{abstract}

Keywords: Coccidiosis; Eimeria tenella; Pathology

\section{Introduction}

Coccidiosis is considered to be one of the major poultry farm diseases throughout the world [1]. Clinical and subclinical forms of the disease are jointly responsible for huge economic losses in the poultry industry [2]. Intracellular protozoan parasites belonging to the genus Eimeria are responsible for causing coccidiosis in Chicken [3]. These parasites reside and multiply in the intestinal mucosa. The disease is characterized by enteritis, dysentery, drooping wings, emaciation, poor growth, low production [4] and responsible for high mortality rate and increased morbidity [5].
Mortality rate is found to be highest among young chicks as most of the Eimeria species infect chicks between the age of 3 weeks to 18 weeks. Seven species of Eimeria have been recognized which vary in their degrees of pathogenicity. These include E. acervulina, E. maxima, E. brunetti, E. necatrix, E. mitis, E. praecox and E. tenella.

Eimeria tenella is the most ubiquitous [6] and the most pathogenic coccidian parasite [7-9]. Its infection results in $100 \%$ morbidity and very high mortality due to its severe damage of the digestive tract of the host [10]. Eimeria tenella specifically infect epithelial 
cells of crypts of Lieberkuhn of caecum, resulting in formation of haemorrhagic lesions of varying severity, influenced by parasite load, size and age of the bird, as well as host genotype and previous infection history. The lesions resulting from the infection of this parasite alter nutrient absorption, triggering several changes in the metabolism of carbohydrates, lipid, protein and macro and trace mineral [11]. In view of lack of specific information available regarding the prevalence and tissue damage caused by coccidian parasite Eimeria tenella in poultry sector of Kashmir, the present study was designed to have first hand authentic information about the prevalence of the protozoan in both organized and unorganised types of poultry farms and also report on the extent of tissue damage caused by the parasite at the site of its location posing serious economic threats to the poultry sector of Kashmir valley.

\section{Materials and Methods}

\section{Collection and preservation of intestinal caecae}

A total of 400 samples of intestinal caecae were collected from both organized farms (200 samples) and backyard poultry (200 samples) belonging to various districts covering almost entire Kashmir valley. Birds for sampling were selected on the basis of physical parameters like dullness, raffled feathers, less growth and diarrhoea. After sacrificing the birds by slaughtering, viscera was removed and grossly examined for lesions. Caecae having gross lesions were collected and fixed in $10 \%$ Neutral buffer formalin. The particulars like age of birds and the farm management practices were recorded. The age group of studied flocks of birds was between $3-18 \pm 1.5$ weeks which is the most vulnerable age group for coccidian infection (Shiraz., et al. 2011).

Wet smear method

Deeper scrapings were taken from caecum and wet smears were prepared for microscopic examination of coccidial oocyst [12].

\section{Impression smear cytological examination}

Impression smears were made from caecum, which were then stained with Giemsa stain [13].

\section{Morphometry of oocyst}

Identification of particular Coccidian species was done on the basis of morphological features of Oocyst like shape, size, colour, appearance of the wall, presence or absence of micropyle and micropylar cap and sporulation time [14-17].

\section{Histopathological examination of caecal lesions}

For histological examination, representative tissue samples of caecum were collected in $10 \%$ Neutral buffer formalin and then processed for paraffin embedding. The sections were cut at $5 \mu \mathrm{m}$ thick and were then stained by Harris haematoxylin and eosin method [18].

\section{Data entry and analysis}

A computer program (SPSS 10.05 for windows; SPSS Inc., Chicago, Illinois, USA) was used for analysis of data. The chi-square test was used to observe any statistical significance. Differences were considered significant when $P$ values of less than 0.05 were obtained.

\section{Ethical clearance}

The study was cleared by the Research ethics committee of Government S P College, Cluster University Srinagar. Unofficial meetings were held with the owners of organized poultry farms and with the household owners rearing backyard poultry in order to explain the protocol of the study and informed consent form was taken from them.

\section{Results}

The infection percentage of Eimeria tenella in backyard chicken was observed to be higher i.e 35.5\% as compared to organized poultry farm where the infection rate was only $24 \%$ (Table 1). Among the organized poultry, the prevalence based on the management system was found to be $37.2 \%$ and $12.3 \%$ in poor and good management system respectively with significant difference between poorly and properly managed chicken $(\mathrm{p}<0.05)$. The study also revealed that in unorganized backyard poultry, E. tenella showed 
Prevalence and Pathology Associated with Coccidian Parasite Eimeria tenella in Organised and Unorganised Poultry of Kashmir Valley, India

mixed infection with E. maxima in $15.49 \%$ of infected birds and coinfection with E. acervulina in $2.81 \%$ of infected birds. On the other hand, in organized poultry only E. tenella and E. maxima co-infection was reported in $6.25 \%$ of infected cases. Monthwise prevalence studies reveal highest prevalence rates during September months of both the years of study with $76.47 \%$ prevalence in unorganised birds and $64.7 \%$ in organized birds and no infection was reported in January months of both the years of study (Table 2 ). The infection was observed in all the seasons of year (Table 3) but the prevalence was significantly higher $(\mathrm{p}<0.05)$ in the autumn (48\% in organized and $62 \%$ in unorganized birds) followed by summer (32\% in organized and 50\% in unorganized birds), spring (12\% in organized and $24 \%$ in unorganized) and least prevalence was reported in winter (4\% in organized and 6\% in unorganized).

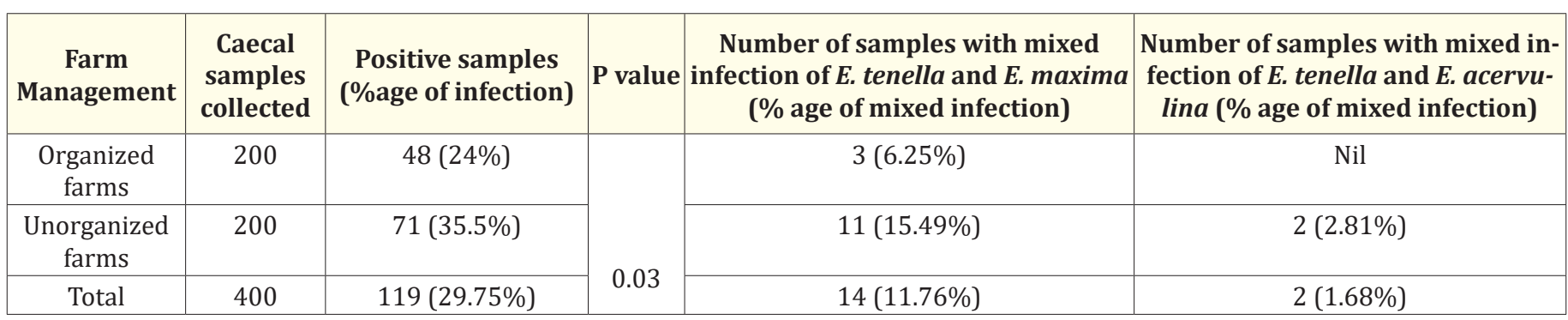

Table 1: Prevalence of Eimeria tenella mono-infection and co-infection in organized and unorganized backyard poultry of Kashmir valley.

\begin{tabular}{|c|c|c|c|c|c|}
\hline \multicolumn{2}{|c|}{$\begin{array}{l}\text { Month and Year of col- } \\
\text { lection }\end{array}$} & \multirow{2}{*}{\begin{tabular}{|c|}
$\begin{array}{c}\text { Total number of } \\
\text { samples screened } \\
\text { from organized farms }\end{array}$ \\
8 \\
\end{tabular}} & \multirow{2}{*}{$\begin{array}{c}\begin{array}{c}\text { Total number of } \\
\text { positive samples } \\
\text { (Prevalence \%) }\end{array} \\
0(0)\end{array}$} & \multirow{2}{*}{$\begin{array}{c}\text { Total number of samples } \\
\text { screened from unorga- } \\
\text { nized backyard poultry }\end{array}$} & \multirow{2}{*}{$\begin{array}{c}\begin{array}{c}\text { Total number of } \\
\text { positive samples } \\
\text { (Prevalence \%) }\end{array} \\
0(0)\end{array}$} \\
\hline Jan & 2018 & & & & \\
\hline & 2019 & 9 & $0(0)$ & 9 & $0(0)$ \\
\hline & Total & 17 & $0(0)$ & 17 & $0(0)$ \\
\hline \multirow[t]{3}{*}{ Feb } & 2018 & 9 & 1 (11.11) & 9 & 1 (11.11) \\
\hline & 2019 & 8 & $0(0)$ & 8 & $1(12.5)$ \\
\hline & Total & 17 & $1(5.88)$ & 17 & 2 (11.76) \\
\hline \multirow[t]{3}{*}{ March } & 2018 & 8 & $0(0)$ & 8 & $1(12.5)$ \\
\hline & 2019 & 8 & $1(12.5)$ & 8 & $2(25)$ \\
\hline & Total & 16 & $1(6.25)$ & 16 & 3 (18.75) \\
\hline \multirow[t]{3}{*}{ April } & 2018 & 9 & $1(11.11)$ & 9 & $2(22.22)$ \\
\hline & 2019 & 8 & $1(12.5)$ & 8 & $3(37.5)$ \\
\hline & Total & 17 & $2(11.76)$ & 17 & $5(29.4)$ \\
\hline \multirow[t]{3}{*}{ May } & 2018 & 8 & $1(12.5)$ & 8 & $2(25)$ \\
\hline & 2019 & 9 & $2(22.22)$ & 9 & $2(22.22)$ \\
\hline & Total & 17 & $3(17.64)$ & 17 & $4(23.52)$ \\
\hline \multirow[t]{3}{*}{ June } & 2018 & 8 & $2(25)$ & 8 & $3(37.5)$ \\
\hline & 2019 & 8 & $1(12.5)$ & 8 & $3(37.5)$ \\
\hline & Total & 16 & 3 (18.75) & 16 & $6(37.5)$ \\
\hline \multirow[t]{3}{*}{ July } & 2018 & 9 & $4(44.44)$ & 9 & $6(66.66)$ \\
\hline & 2019 & 8 & $2(25)$ & 8 & $4(50)$ \\
\hline & Total & 17 & $6(35.29)$ & 17 & $10(58.82)$ \\
\hline
\end{tabular}

Citation: Sheikh Tanveer Salam and Showkat Ahmad Wani. "Prevalence and Pathology Associated with Coccidian Parasite Eimeria tenella in Organised and Unorganised Poultry of Kashmir Valley, India". Acta Scientific Microbiology 4.4 (2021): 100-104. 


\begin{tabular}{|c|c|c|c|c|c|}
\hline \multirow[t]{3}{*}{ Aug } & 2018 & 8 & $4(50)$ & 8 & $5(62.5)$ \\
\hline & 2019 & 9 & $3(33.33)$ & 9 & $4(44.44)$ \\
\hline & Total & 17 & 7 (41.17) & 17 & $9(52.94)$ \\
\hline \multirow[t]{3}{*}{ Sep } & 2018 & 9 & $6(66.66)$ & 9 & 7 (77.77) \\
\hline & 2019 & 8 & $5(62.5)$ & 8 & $6(75)$ \\
\hline & Total & 17 & $11(64.7)$ & 17 & $13(76.47)$ \\
\hline \multirow[t]{3}{*}{ Oct } & 2018 & 8 & $4(50)$ & 8 & $5(62.5)$ \\
\hline & 2019 & 8 & $3(37.5)$ & 8 & $5(62.5)$ \\
\hline & Total & 16 & $7(43.75)$ & 16 & $10(62.5)$ \\
\hline \multirow[t]{3}{*}{ Nov } & 2018 & 8 & $3(37.5)$ & 8 & $4(50)$ \\
\hline & 2019 & 9 & 3 (33.33) & 9 & $4(44.44)$ \\
\hline & Total & 17 & $6(35.29)$ & 17 & $8(47.05)$ \\
\hline \multirow[t]{3}{*}{ Dec } & 2018 & 8 & $0(0)$ & 8 & $1(12.5)$ \\
\hline & 2019 & 8 & $1(12.5)$ & 8 & $0(0)$ \\
\hline & Total & 16 & $1(6.25)$ & 16 & $1(6.25)$ \\
\hline \multirow{3}{*}{$\begin{array}{l}\text { Jan to } \\
\text { Dec }\end{array}$} & 2018 & 100 & $26(26)$ & 100 & 37 (37) \\
\hline & 2019 & 100 & $22(22)$ & 100 & $34(34)$ \\
\hline & Grand Total & 200 & $48(24)$ & 200 & $71(35.5 \%)$ \\
\hline
\end{tabular}

Table 2: Monthwise prevalence of Eimeria tenella in organized and unorganized backyard poultry of Kashmir Valley.

\begin{tabular}{|c|c|c|c|c|}
\hline \multicolumn{2}{|c|}{$\begin{array}{c}\text { Season and Year of } \\
\text { Collection }\end{array}$} & $\begin{array}{c}\text { Number of samples examined } \\
\text { (Organized/Unorganized) }\end{array}$ & $\begin{array}{c}\text { Number of positive samples } \\
\text { (Organized/Unorganized) }\end{array}$ & $\begin{array}{c}\text { Prevalence (\%) } \\
\text { (Organized/Unorganized) }\end{array}$ \\
\hline \multirow{2}{*}{$\begin{array}{c}\text { Spring (Mar, Apr, } \\
\text { and May) }\end{array}$} & 2018 & $50(25 / 25)$ & $7(2 / 5)$ & $14(8 / 20)$ \\
\cline { 2 - 5 } & 2019 & $50(25 / 25)$ & $11(4 / 7)$ & $18(12 / 24)$ \\
\cline { 2 - 5 } & Total & $100(50 / 50)$ & $18(6 / 12)$ & $46(40 / 56)$ \\
\hline \multirow{4}{*}{$\begin{array}{c}\text { Summer (June, July, } \\
\text { and Aug) }\end{array}$} & 2018 & $50(25 / 25)$ & $23(10 / 14)$ & $34(24 / 44)$ \\
\cline { 2 - 5 } & 2019 & $50(25 / 25)$ & $17(6 / 11)$ & $40(32 / 50)$ \\
\cline { 2 - 5 } & Total & $100(50 / 50)$ & $29(16 / 25)$ & $58(52 / 64)$ \\
\hline \multirow{2}{*}{$\begin{array}{c}\text { Autumn (Sep, Oct } \\
\text { and Nov) }\end{array}$} & 2018 & $50(25 / 25)$ & $26(11 / 15)$ & $52(44 / 60)$ \\
\cline { 2 - 5 } & 2019 & $50(25 / 25)$ & $55(24 / 31)$ & $55(48 / 62)$ \\
\cline { 2 - 5 } & Total & $100(50 / 50)$ & $3(1 / 2)$ & $6(4 / 8)$ \\
\hline \multirow{2}{*}{$\begin{array}{c}\text { Winter (Dec, Jan } \\
\text { and Feb) }\end{array}$} & 2018 & $50(25 / 25)$ & $2(1 / 1)$ & $4(4 / 4)$ \\
\cline { 2 - 5 } & 2019 & $50(25 / 25)$ & $5(2 / 3)$ & $5(4 / 6)$ \\
\cline { 2 - 5 }
\end{tabular}

Table 3: Season wise prevalence of Eimeria tenella in organized and unorganized backyard poultry of Kashmir Valley.

Oocysts were seen in wet smear examination of positive faecal samples, where as Eimerian oocysts and schizonts were observed in impression smear examination. The post-mortem examination revealed lesions of caecal coccidiosis. Gross pathology included ballooning of caeca [Figure 1(A)] and severe infection was associated with petechial hemorrhage in caecum [Figure 1(B)]. In severe cases of caecal coccidiosis, characteristic bloody mass was observed on opening of the caeca. Histological studies revealed presence of oocysts at different stages of development in the epithelial cells of submucosal glands of caecum (arrow head) and microgametes (arrow) were found to be free within lamina propria with massive infiltration of heterophils and mononuclear cells [Figure
2(A)] when compared to normal caecum. Presence of numerous intracellular schizonts containing merozoites (arrow) can be seen with severe submucosal hemorrhage [Figure 2(B)]. Intense congestion of blood vessels of sub-mucosa, fibrosis and oedema with degeneration of glandular epithelium harbouring coccidian life-cycle stages and also shedding of oocysts in the glandular lumen was observed. Moreover, blood clots and fibrino-caseous materials were observed in the lumen of caeca. In some cases, different developmental stages of the parasite were transmurally located throughout the mucosa and necrosis was found to be more severe in the regions where there were massive accumulations of schizonts with merozoites. Histological studies of lesions demonstrated fusion of 
villi and severe villous atrophy, marked proliferation of epithelial cells of crypts, foci of intense mononuclear infiltrate at the sub mucosa membrane.

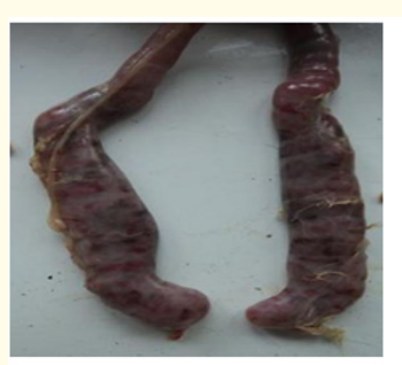

(A)

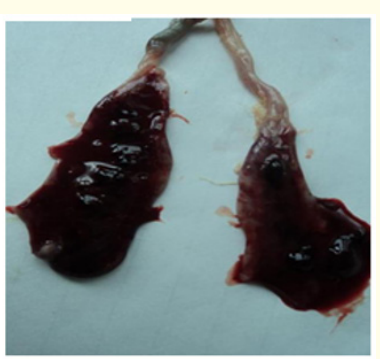

(B)

\section{Figure 1}

(A) Photograph showing distension and ballooning of caecum in caecal coccidiosis.

(B) Photograph of Caecum with petechial hemorrhage during caecal coccidiosis.

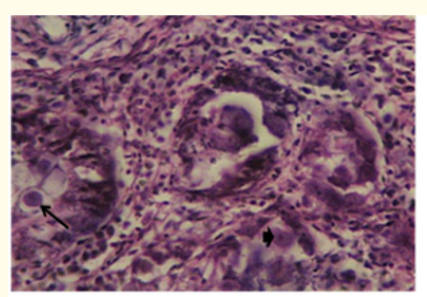

(A)

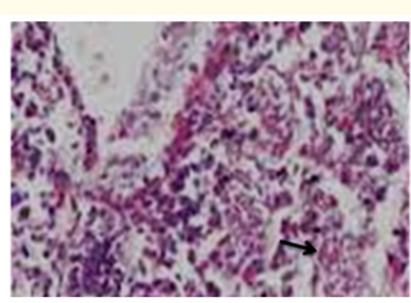

(B)
Figure 2

(A) Photomicrograph of caecum showing presence of oocysts (arrow head) and microgametes (arrow) free within lamina propria with massive infiltration by heterophils and mononuclear cells (H\&E x 400).

(B) Photomicrograph of Caecum showing numerous intracellular schizonts containing merozoites (arrow) can be seen with severe submucosal hemorrhage (H\&E x 400).

\section{Discussion and Conclusion}

Higher rates of infection in unorganized chicken compared to organized birds observed in the current study is in agreement with the findings of S. Sharma., et al. [19] who also reported higher coccidian infection percentage $(53.61 \%)$ in unorganized farms compared to organized farms (25.55\%) in Jammu region of J\&K. This difference in infection percentage in two patterns of poultry raising can be attribute to the fact that backyard birds are freely foraging thereby get more exposed to the parasitic infections compared to organized birds. Co-infection of Eimeria tenella with other species of Eimeria observed in both types of poultry systems may be attributed to the bad management conditions where birds are exposed to a high-risk infection by different pathogens at the same time. Higher prevalence rates in poorly managed organised farms may be due to poor poultry management practices like overcrowding, leaking water troughs, accumulation of droppings and absence of proper disposal of litter. Highest infection rates observed in the present study during autumn with higher temperature and humidity are in line with the observations of Sharma., et al. [19] but unlike their observations lowest prevalence was recorded in winter instead of summer. This high prevalence in the autumn season in Kashmir could be attributed to sudden drop in temperature after hot summer and increase in humidity, which is conducive for sporulation of oocysts for easy dispersion and transmission. Lowering of host resistance during higher temperatures buttresses the parasitic infections in the hosts during warm moist periods. The lowest infection during winter can be attributed to the harsh winter peculiar in Kashmir which suspends the development of parasitic stages.

Gross and histological changes due to Eimeria tenella infection observed in this study coincide with those of other workers [20-24]. These authors have also reported enlargement of caecum with clotted blood, haemorrhages throughout the mucosal lining of caeca and change in coloration from reddish to milky white. Infiltration of heterophils and mononuclear cells observed in this study were similar to those of Rasheda and Bano [25]. They have also reported severe oedema and sub-mucosal errosion, glandular tissue cells infiltration and atrophy of villi. Findings of several merozoites, schizonts and microgametes in the epithelial cells were also reported by earlier workers [26,27].

\section{Conflict of Interest}

There was no conflict of interest in this study.

\section{Bibliography}

1. Amer MM., et al. "Isolation and identification of Eimeria from field coccidiosis in chickens". Journal of American Science 6.10 (2010): 1107-1114.

2. Lilic S., et al. "Coccidiosis in poultry industry". Technologija Mesa 50 (2009): 90-98.

3. Waldenstedt L., et al. "Sporulation of Eimeria maxima oocysts in litter with different moisture contents". Poultry Science 80 (2001): 1412-1415.

4. Awais M M., et al. "Seasonal prevalence of coccidiosis in industrial broiler chickens in Faisalabad, Punjab, Pakistan". Tropical Animal Health and Production 44.2 (2012): 323-328.

5. Shiraz MR., et al. "Prevalence and risk factors for subclinical coccidiosis in broiler chicken farms in Mazandaran province, Iran". Tropical Animal Health and Production 43 (2011): 16011604. 
6. Quarzane M., et al. "Eimeria tenella: cloning and characterization of cDNA encoding a S3a ribosomal protein". Gene 225 (1998): 125-130.

7. Arakawa A and Xie MQ. "Control of coccidiosis in chicken". Journal of Protozoology Research 3 (1993): 31-39.

8. Yadav A and Gupta SK. "Study of resistance against some ionophores in Eimeria tenella field isolates". Veterinary Parasitology 102 (2001): 69-75.

9. Ayaz M., et al. "Prevalence of coccidiosis in broiler chickens in Faisalabad, Pakistan”. Pakistan Veterinary Journal 23 (2003): 51-52.

10. Cook GC. "Small intestinal coccidiosis: an emergent clinical problem". Journal of Infection 16 (1988): 213-219.

11. Witlock DR., et al. "Scanning electron microscopy of Eimeria tenella infection and subsequent repair in chicken caeca". Journal of Comparative Pathology 85 (1975): 571-581.

12. Fleck SL and Moody AH. "Diagnostic technique in medical parasitology, 11th Edition". Cambridge University Press, Cambridge (1993): 10-14

13. Osorio C., et al. "Cytological diagnosis of coccidial infections in turkeys". Alpharma Animal Health 33 (2010): 3

14. Lima JD. "Eimeria caprina sp. from the domestic goat (Capra hircus) from the United States of America". Journal of Parasitology 65.6 (1979): 902-903.

15. Soulsby E J L. "Helminths, Arthropods and Protozoa of Domesticated Animals". 8th Edition Page: 809. English Language Book Society and Baillere Tindal, London (1982).

16. Levine ND. "Veterinary Protozoology". Iowa State University Press, Ames (1985): 414.

17. Smith MC and Sherman DM. "Goat medicine". 2nd Ed. WileyBlackwell, Philadelphia (1994): 429-431.

18. Luna LG. "Manual of histological staining methods of the armed registry of pathology". 3rd edition. Mc Graw Hill, New York (1968): 36-95.

19. S Sharma., et al. "Study of poultry coccidiosis in organized and backyard farms of Jammu region". Veterinary World 6.8 (2013): 467-469.
20. Tyzzer EE. “Coccidiosis in gallinaceous birds". American Journal of Tropical Medicine and Hygiene 10 (1929): 269.

21. Johnson WT. "A Study on Eimeria necatrix". Agricul Experi Station Tech Bull 538 (1930): 30-33.

22. Davis SFM. "Eimeria brunette and additional cause of intestinal coccidiosis in poultry domestic fowl”. Brazilian Veterinary Record 75 (1963): 1-4.

23. Raillet F and Lucet M. "An account of coccidiosis in the domestic fowl". Veterinary Medicine 2 (1891): 661-663.

24. Fantham HB. "The morphology and life-history of Eimeria (coccidium) avium: a sporozoo"n causing a fatal disease among young grouse". Proceed Zoolo Socie of London 3 (1910): 672691.

25. Rasheda M and Bano L. "Histopathology of coccidiosis by Eimeria garnhami in Coturnix coturnix of N.W.F.P”. Pakistan Veterinary Journal 1 (1985): 27-29.

26. Soomro NM., et al. "Clinical, gross and histopathological studies of coccidial infection in chicken". Intern Journal of Agriculture And Biology 3.4 (2001): 426-427.

27. Sood S., et al. "Prevalence of coccidiosis in poultry birds in R.S. Pura region, Jammu". Veterinary Practice 10.1 (2009): 69-70.

\section{Assets from publication with us}

- Prompt Acknowledgement after receiving the article

- Thorough Double blinded peer review

- Rapid Publication

- Issue of Publication Certificate

- High visibility of your Published work

Website: https://www.actascientific.com/

Submit Article: https://www.actascientific.com/submission.php Email us: editor@actascientific.com

Contact us: +919182824667 